\section{Conservation practice effectiveness in the irrigated Upper Snake River/Rock Creek watershed}

\author{
D.L. Bjorneberg, D.T. Westermann, N.O. Nelson, and J.H. Kendrick
}

\begin{abstract}
The Upper Snake River/Rock Creek Conservation Effects Assessment Project was initiated in 2005 to determine the effectiveness of conservation practices in an irrigated watershed. Our objectives were to determine water and salt balances and water quality effects of using sprinkler rather than furrow irrigation in the Twin Falls irrigation tract in southern Idaho. Data from the current study were compared with earlier studies conducted from 1968 to 1971. Irrigation water diverted from the Snake River supplied $73 \%$ and $83 \%$ of the hydrologic input to this 82,000 ha $(202,000 \mathrm{ac})$ watershed in 2005 and 2006, respectively, with approximately $40 \%$ flowing back to the Snake River through furrow irrigation runoff, unused irrigation water, and subsurface drainage. Net suspended sediment loss decreased from $460 \mathrm{~kg} \mathrm{ha}^{-1}\left(400 \mathrm{lb} \mathrm{ac}^{-1}\right)$ during the 1971 irrigation season to $220 \mathrm{~kg} \mathrm{ha}^{-1}\left(190 \mathrm{lb} \mathrm{ac}^{-1}\right)$ in 2005 and $10 \mathrm{~kg} \mathrm{ha}^{-1}\left(9 \mathrm{lb} \mathrm{ac}^{-1}\right)$ in 2006 by switching from furrow to sprinkler irrigation, applying polyacylamide, and installing sediment ponds. The relative amount of sprinkler irrigation in a subwatershed did not correlate with the total loss of suspended sediment for July 2005 and $2006(r=0.12)$. The lack of correlation was primarily due to extremely high sediment concentrations in two of the five subwatersheds, possibly due to furrow irrigation management. Two potential concerns identified during this initial analysis were an accumulation of total salts in the watershed and increased nitrate concentrations in four return flow streams compared to earlier studies. Future analyses will determine the effects of specific practices with this watershed.
\end{abstract}

Key words: Conservation Effects Assessment Project (CEAP)-furrow irrigationsprinkler irrigation-water balance

The Upper Snake River/Rock Creek water-
shed is a $\mathbf{6 , 3 0 0 ~} \mathbf{~ k m}^{\mathbf{2}}\left(\mathbf{2 , 4 3 0} \mathbf{~ m i}^{\mathbf{2}}\right)$ area
located along the Snake River in south-
ern Idaho. Range and forest land $(60 \%)$ and
irrigated cropland (37\%) are the dominant
land uses. The Upper Snake River/Rock
Creek watershed is one of eight USDA
Natural Resources Conservation Service
special emphasis watersheds selected for the
Conservation Effects Assessment Project
(CEAP) in 2004 and is also one of the
14 USDA Agricultural Research Service
Benchmark Watersheds. Since the empha-
sis of the Upper Snake River/Rock Creek
CEAP is irrigated conservation practices,
monitoring and assessment have been lim-
ited to the Twin Falls irrigation tract, an 820
$\mathrm{~km}^{2}\left(316\right.$ mi $\left.{ }^{2}\right)$ agricultural area located along
the south side of the Snake River (figure 1$)$.

Our research objectives for the Upper Snake River/Rock Creek CEAP are to (1) compare current water and salt balances for the tract with earlier data and (2) determine effects of converting from furrow irrigation to sprinkler irrigation on water quantity and quality. The water and salt balances are being calculated by monitoring the quantity and quality water of water flowing into the watershed and returning to the Snake River (salt balance sites). A multiple watershed approach is being used with five small watersheds within the Twin Falls tract to determine the effects of converting to sprinkler irrigation (subwatershed sites). A third objective of the Upper Snake River/Rock Creek CEAP is to adapt a water quality model for use in an irrigated watershed. Existing water quality models, such as the Soil and Water Assessment Tool
(SWAT) and Annualized Agricultural NonPoint Source (AnnAGNPS), do not predict irrigation-induced soil erosion and cannot completely simulate irrigation hydrology similar to the Twin Falls tract.

This paper describes the characteristics of the Twin Falls irrigation tract and monitoring that began in 2005 to determine the effects of conservation practices in an irrigated watershed. Water, sediment, salt, and nutrient balances from current monitoring and previous studies (1968 to 1971) are included to indicate overall changes in water quality as conservation practices have been implemented.

General Watershed Characteristics. The Twin Falls irrigation tract is bounded on the north and west by deeply incised canyons (100 to $150 \mathrm{~m}$ deep [300 to $500 \mathrm{ft}$ ]) of the Snake River and Salmon Falls Creek. The Twin Falls Main Canal forms the eastern boundary, and the High Line Canal forms the southern boundary. Rock Creek is the only stream contributing significant flow to the Twin Falls tract, and this stream often does not flow from June through September due to upstream irrigation diversions. Other streams flowing to the Snake River within the Twin Falls tract originate within the tract from furrow irrigation runoff, unused irrigation water, and subsurface drainage (figure 1).

All crop production within the Twin Falls tract is irrigated because average annual precipitation is only $270 \mathrm{~mm}$ (11 in). Since 1905, the Twin Falls Canal Company (TFCC) has supplied irrigation water to this area. Water is diverted from the Snake River at Milner Dam and routed through $180 \mathrm{~km}(110 \mathrm{mi})$ of main canals and over $1,600 \mathrm{~km}(1,000 \mathrm{mi})$ of smaller channels and laterals. The TFCC has over 3,000 service gates (headgates) for delivering water to fields. Irrigation water flows by gravity from the Snake River throughout the 82,000 ha $(202,000 \mathrm{ac})$ watershed. Natural channels or coulees often convey water to laterals and collect runoff and return flow from fields.

David L. Bjorneberg is an agricultural engineer and Dale T. Westermann is a retired soil scientist for the USDA Agricultural Research Service Northwest Irrigation and Soils Research Laboratory, Kimberly, Idaho. Nathan $\mathbf{0}$. Nelson is an assistant professor in the Agronomy Department, Kansas State University, Manhattan, Kansas. John H. Kendrick is a planning specialist, USDA Natural Resources Conservation Service, Boise, Idaho. 


\section{Figure 1}

Aerial photograph of the Twin Falls irrigation tract showing the subwatershed areas and salt balance monitoring sites for the 2005 irrigation season.

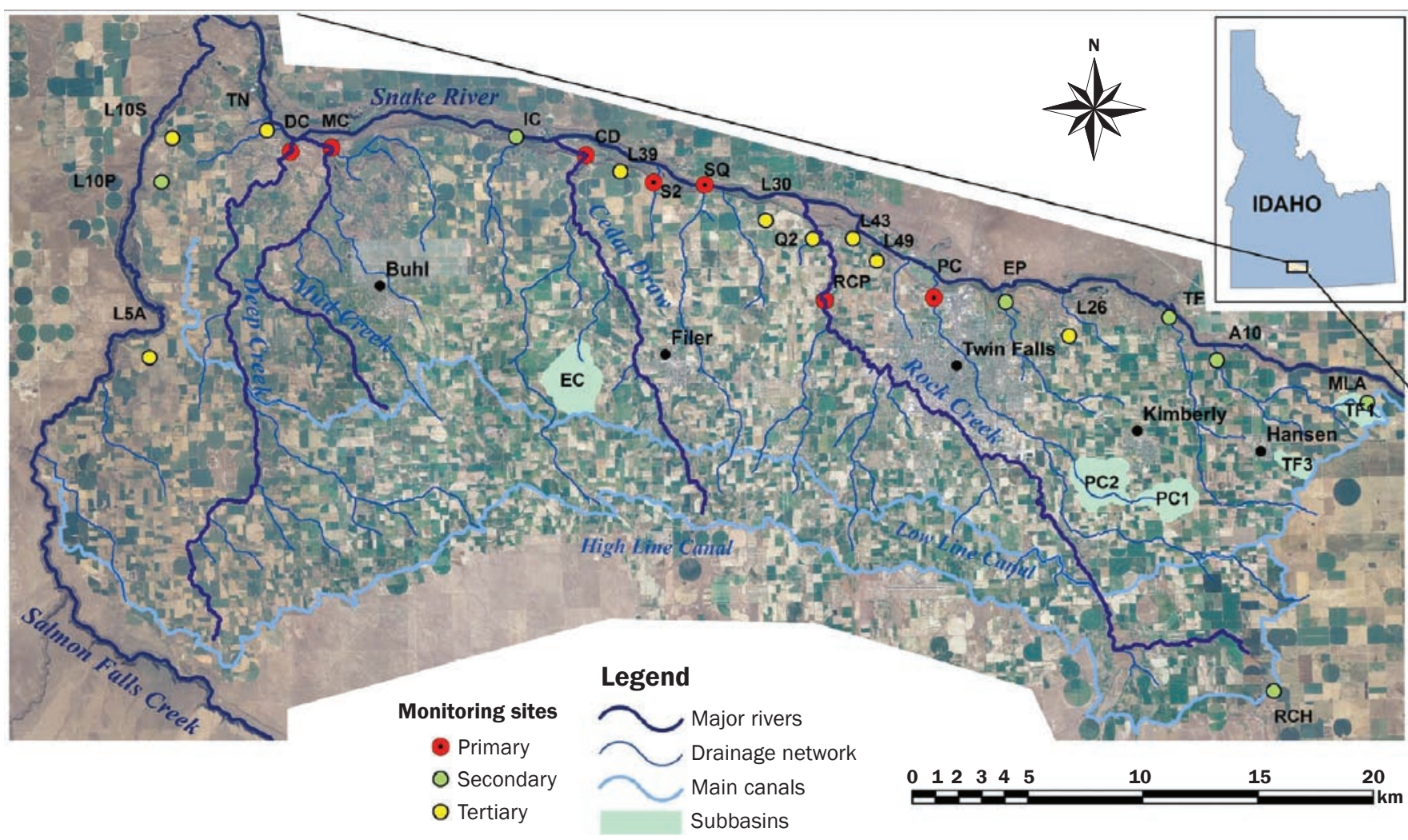

Water only flows in these coulees during the irrigation season (April through October) unless subsurface drains contribute flow during the non-irrigation season.

The TFCC is the largest canal company in Idaho and supplies water to about $85 \%$ of the irrigated land in Twin Falls County (USDA National Agricultural Statistics Service [NASS] 2007). Typical crops are alfalfa (Medicago sativa L.), barley (Hordecum vulgare L.), spring and winter wheat (Triticum aestivum L.), dry bean (Phaseolus vulgaris L.), sugar beet (Beta vulgaris L.), potato (Solanum tuberosum L.), and corn (Zea mays L.). The TFCC allocates water on a flow-rate basis. The original project planned to divert 85 $\mathrm{m}^{3} \mathrm{~s}^{-1}\left(3,000 \mathrm{ft}^{3} \mathrm{sec}^{-1}\right)$ to irrigate 97,000 ha $(240,000 \mathrm{ac})$ using the natural flow of the river (Moon and Tremayne 2005). Water is continually available at $52 \mathrm{~L} \mathrm{~min}^{-1} \mathrm{ha}^{-1}(5.6$ gal $\mathrm{min}^{-1} \mathrm{ac}^{-1}$ ) during the irrigation season that extends approximately from April 20 to October 20. Although water is continually available, it is not practical to continually use this rate of water for the entire irrigation season, especially during the spring and fall. Conversely, this flow rate allocation is approximately $7.6 \mathrm{~mm} \mathrm{~d}^{-1}\left(0.30\right.$ in day $\left.^{-1}\right)$, which is less than peak water use for many crops during the summer. Consequently, farmers typically grow a variety of crops to spread irrigation demand throughout the irrigation season to better balance irrigation supply with crop demand.

Seepage from canals and laterals and deep percolation from furrow irrigated fields raised the water table in some areas of the Twin Falls tract. The TFCC began constructing $1.2-\mathrm{m}$ (4-ft) wide by $1.8-\mathrm{m}(6-\mathrm{ft})$ high drainage tunnels to remove excess water. Approximately 50 tunnels ranging from 400 to $2,400 \mathrm{~m}$ (0.25 to $1.5 \mathrm{mi})$ long were constructed until the 1930s (Carter et al. 1971). Additional drain tiles and drainage wells were installed until the late 1940s. Water from these subsurface drain tunnels and tiles flows to natural channels or coulees that flow into the Snake River.

The Twin Falls irrigation tract has historically been furrow irrigated, with less than $10 \%$ of the land sprinkler irrigated until the 1980s. Many fields have been converted to sprinkler irrigation since the mid-1990s with financial assistance from the Environmental
Quality Incentive Program and other special projects. The Environmental Quality Incentive Program has provided over $\$ 4$ million for conservation practices in Twin Falls County from 2002 to 2006. Approximately 90\% of Environmental Quality Incentive Program funds have been used for sprinkler systems (Schuyler, personnel communication, May 29, 2007).

Natural Resources Concerns. Irrigation return flow monitoring during three studies from 1968 to 1971 showed that the Twin Falls irrigation tract had a net loss of sediment, nitrate, and total salts, and a net gain of soluble phosphorus (Brown et al. 1974; Carter et al. 1971, 1974). These studies were conducted when about $95 \%$ of the land in the Twin Falls tract was furrow irrigated, and some results are summarized in table 1 . The 1969 data were collected from October 1968 to September 1969, while the 1971 data were only collected during the irrigation season (May to September). The large difference in outflows between 1969 and 1971 were a result of different methods of accounting for subsurface return flow to the Snake River. Carter et al. (1971) measured $471 \mathrm{~mm}$ (18.5 
Table 1

Water, sediment, nutrient, and salt data for the 1969 water year (October through September) and from May to September 1971 on the Twin Falls irrigation tract.

\begin{tabular}{|c|c|c|c|c|c|c|}
\hline \multicolumn{2}{|c|}{ Water year } & \multirow{2}{*}{$\begin{array}{l}\text { Water }(\mathrm{mm}) \\
1,990\end{array}$} & \multirow{2}{*}{$\begin{array}{c}\begin{array}{l}\text { Suspended sediment } \\
\left(\mathrm{kg} \mathrm{ha}^{-1}\right)\end{array} \\
\text { NA }\end{array}$} & \multirow{2}{*}{$\begin{array}{c}\begin{array}{l}\text { Dissolved P } \\
\left(\mathbf{k g ~ h a}^{-1}\right)\end{array} \\
1.02\end{array}$} & \multirow{2}{*}{$\begin{array}{c}\begin{array}{c}\text { Nitrate-N } \\
\left(\mathbf{k g ~ h a}^{-1}\right)\end{array} \\
2\end{array}$} & \multirow{2}{*}{$\begin{array}{c}\begin{array}{l}\text { Soluble salts } \\
\text { (kg ha-1) }^{-1}\end{array} \\
5,760\end{array}$} \\
\hline $1969 *$ & Irrigation inflow & & & & & \\
\hline & Surface outflow & 310 & NA & 0.20 & 1 & 900 \\
\hline & Subsurface outflow & $1,090 \ddagger$ & NA & 0.10 & 35 & 7,260 \\
\hline & Difference (inflow - outflow) & $590 \S$ & & 0.72 & -34 & $-2,400$ \\
\hline \multirow[t]{3}{*}{$1971 \dagger$} & Irrigation inflow & 1,690 & 920 & 0.35 & NA & NA \\
\hline & Outflow & $460 \|$ & 1,380 & 0.31 & NA & NA \\
\hline & Difference (inflow - outflow) & 1,230\# & -460 & 0.04 & & \\
\hline
\end{tabular}

* Data from Carter et al. (1971).

† Data from Carter et al. (1974).

$\ddagger$ All inflow and precipitation $(200 \mathrm{~mm})$ that was not accounted for by surface outflow $(310 \mathrm{~mm})$ or estimated evapotranspiration $(790 \mathrm{~mm})$ was considered subsurface outflow.

$\S$ The difference plus $200 \mathrm{~mm}$ of precipitation equals $790 \mathrm{~mm}$ of estimated evapotranspiration.

|| Only includes measured surface return flow from 18 sites.

\# Precipitation and evapotranspiration were not included in the analysis.

in) of return flow from the four major natural streams in the irrigation tract (Rock Creek, Cedar Draw, Mud Creek, and Deep Creek). Using base-flow separation techniques, they estimated $310 \mathrm{~mm}$ (12.2 in) of surface runoff. Subsurface return flow was estimated as $1,090 \mathrm{~mm}$ (43 in), which is the difference of their mass-balance (irrigation + precipitation - evapotranspiration (ET) - surface runoff $=$ subsurface return flow). Carter et al. (1974) only measured inflow and outflow and did not account for ET and subsurface return flow. Thus, the net losses of 2,400 kg $\mathrm{ha}^{-1}\left(2,100 \mathrm{lb} \mathrm{ac} \mathrm{c}^{-1}\right)$ of total salts and $34 \mathrm{~kg}$ $\mathrm{ha}^{-1}\left(30 \mathrm{lb} \mathrm{ac}^{-1}\right)$ of nitrate-N (Carter et al. 1971) include the estimated salt and nitrate losses from subsurface return flow to the Snake River. The net loss of total salts was a good indication for the sustainability of this irrigated watershed, but the net losses of 34 $\mathrm{kg} \mathrm{ha}^{-1}\left(30 \mathrm{lb} \mathrm{ac}^{-1}\right)$ nitrate-N (Carter et al. 1971) and $460 \mathrm{~kg} \mathrm{ha}^{-1}\left(410 \mathrm{lb} \mathrm{ac}^{-1}\right)$ of sediment (Carter et al. 1974) were a concern.

Irrigation-induced soil erosion remains the predominant natural resource concern in this watershed. Water flowing in irrigation furrows detaches and transports soil. Eroded sediment and associated nutrients are then transported back to the Snake River with irrigation return flow. It is impractical to contain irrigation runoff on furrow irrigated fields in this area because field slopes are typically $1 \%$ to $2 \%$, and some irrigation runoff is desired to achieve acceptable irrigation uniformity. Berg and Carter (1980) found that $20 \%$ to $50 \%$ of applied irrigation water ran off fields in the Twin Falls tract. Soil loss from these fields varied from 1 to $141 \mathrm{Mg} \mathrm{ha}^{-1}$ (0.4 to $\left.63 \mathrm{tn} \mathrm{ac}^{-1}\right)$ annually. In a more recent study, annual soil loss of 2 to $33 \mathrm{Mg} \mathrm{ha}^{-1}\left(0.9\right.$ to $\left.15 \mathrm{tn} \mathrm{ac}{ }^{-1}\right)$ was measured on six commercial furrow irrigated fields (Bjorneberg et al. 2007).

Land use in the Twin Falls irrigation tract continues to change as urban population and dairy production increase. According to the US Census Bureau population estimates, Twin Falls County population increased about $2 \%$ per year, from 53,600 in 1990 to 69,500 in 2005 (US Census Bureau 2007). Population growth rate in the seven communities within the Twin Falls tract was slightly greater at $2.3 \%$ per year from 36,100 in 1990 to 48,500 in 2005 . A more rapid change has been the recent increase in dairy production. Idaho is now the fourth leading dairy state in the United States (USDA NASS 2007). In Twin Falls County, the number of dairy cows has increased from 25,000 in 1995 to 55,000 in 2005 (USDA NASS 2007). While the number of dairy cows increased, the number of dairy farms in Twin Falls County decreased from 144 to 75 between 1987 and 2002 , and the number of dairy farms with more than 500 cows increased from 2 to 32 (USDA NASS 2007).

Increased dairy production has influenced crop production in Twin Falls County. Corn production increased from 4,660 ha $(11,500$ ac) in 1995 to 15,700 ha $(38,800 \mathrm{ac})$ in 2005 . There has be a corresponding decrease in dry bean production from 18,500 to 10,400 ha
$(45,700$ to $25,800 \mathrm{ac})$. Alfalfa also increased from 21,000 to 26,000 ha $(53,000$ to 64,000 ac). Wheat, barley, sugar beet, and potato areas have remained relatively unchanged in Twin Falls County. More irrigation water is generally required to grow corn or alfalfa than dry bean so the shift in crop production has likely increased consumptive use of irrigation water.

\section{Materials and Methods}

The monitoring infrastructure on the Upper Snake River/Rock Creek watershed was incomplete before being selected as a special emphasis CEAP watershed in 2004. Irrigation return flow was being measured at seven sites by Idaho Department of Water Resources prior to 2005. The TFCC also measured flow in the Main Canal and one return flow site. Water quality was not being monitored at any of these sites. To calculate a complete salt balance, 14 additional flow monitoring sites were established, and water quality sampling was initiated in May 2005. In addition, five subwatersheds within the Twin Falls irrigation tract were identified for more detailed monitoring, which also started in May 2005.

Salt Balance Sites. Monitoring sites for calculating water and salt balances were categorized as primary, secondary, or tertiary sites (figure 1). Flow rates at primary and secondary sites were measured with weirs or calculated from stage-discharge relationships. Flow rates at tertiary sites were calculated from a staff gage measurement on a weir or 
from a weir stick measurement on a concrete TFCC structure. Primary sites had data loggers recording water depth and automatic water samplers collecting time-composite water samples (0.2-L [0.05-gal] subsample every 5 hours in 2-L [0.5-gal] bottles). The three or four 2-L composite samples from each primary site were combined into a weekly composite sample. The 5-hour interval was chosen so samples were not collected at the same time each day. Secondary sites also had data loggers measuring water depth, but a 2-L (0.5-gal) grab sample was collected once per week. Tertiary sites have less flow than primary or secondary sites so water depth was manually measured once per week when 2-L (0.5-gal) grab samples were collected.

There were 23 monitoring sites in 2005: seven primary, seven secondary, and nine tertiary. Two tertiary sites were added in 2006. All seven primary sites plus four secondary and three tertiary sites continued to flow after irrigation diversions stopped in late October due to subsurface drainage.

Crop areas and irrigation methods for the entire Twin Falls tract were estimated by a single field survey each year of one randomly chosen section within each of the 17 townships in the tract. Total area surveyed was 4,400 ha $(11,000 \mathrm{ac})$ or about $5 \%$ of the total land area in the Twin Falls tract. The relative area of each crop type identified by the driving survey was multiplied by the total area of the irrigation tract to determine the total area of each crop. Potential crop water use was calculated by multiplying crop areas by the potential ET for those crops calculated by AgriMet (US Bureau of Reclamation 2007) for the Kimberly, Idaho, site. AgriMet used site-specific weather data and the 1982 Kimberly-Penman ET model developed by the USDA Agricultural Research Service in Kimberly, Idaho, to compute daily reference ET. Reference ET was multiplied by crop coefficients to estimate ET for crops grown in the vicinity of each weather station. Nongrowing season ET was estimated using bare soil ET calculated by Allen and Robison (2007).

Subwatershed Sites. A multiple subwatershed approach was chosen to assess the water quantity and quality effects of converting from furrow to sprinkler irrigation. Five small watersheds within the Twin Falls irrigation tract were chosen for monitoring based on each having a well-defined inflow boundary and a single outlet (figure 1). It is common within the Twin Falls irrigation tract for unused irrigation water and field runoff to be diverted from drainage channels to other fields, making the surface water hydrology very complex. Water was not re-diverted within these five watersheds, which vary from 150 to 600 ha (370 to 1,500 ac) and had $5 \%$ to $50 \%$ of the cropland sprinkler irrigated in 2005. Soils in all watersheds were silt loams, predominantly Portneuf silt loam. One watershed (EC) contained subsurface drains that continued to flow after the irrigation season. A sixth watershed was initially selected but was discontinued due to difficulty obtaining reliable inflow data.

Inflow to each watershed was calculated from TFCC daily records for all headgates in each watershed. Outflow from each watershed was measured with a flume. A data logger with a pressure transducer measured water stage every minute and recorded the hourly average stage and flow rate. An automatic sampler, controlled by the data logger, collected flow proportional samples with a goal of 4 to 5 samples per week. Ten 0.2 $\mathrm{L}(0.05 \mathrm{gal})$ subsamples were composited in each $2 \mathrm{~L}$ sample bottle. The data loggers also recorded cumulative flow volume for each subsample and sample.

Crop production and irrigation practices on the five subwatersheds were recorded through monthly field surveys during the irrigation season. Two or three additional surveys were conducted during the winter and early spring to record tillage practices and manure application.

Sample Processing and Analysis. All salt balance and subwatershed monitoring sites were visited weekly while water was flowing to collect water samples and measure flow rate or download flow data. Water samples were refrigerated until processed the day after collection. During sample processing, samples were stirred for 1 to 2 minutes before measuring $\mathrm{pH}$ and electrical conductivity. A $50-\mathrm{ml}(1.7 \mathrm{oz})$ aliquot was taken for total nitrogen $(\mathrm{N})$ and phosphorus $(\mathrm{P})$ analysis. A second $20-\mathrm{ml}(0.7 \mathrm{oz})$ aliquot was filtered $(0.45 \mu \mathrm{m}$ [0.018 mil]) and analyzed for dissolved nutrients and salts $\left(\mathrm{NO}_{3}, \mathrm{NH}_{4}\right.$, $\mathrm{P}, \mathrm{K}, \mathrm{Ca}, \mathrm{Mg}, \mathrm{Na}, \mathrm{Al}, \mathrm{Fe}, \mathrm{Mn}, \mathrm{Zn}, \mathrm{S}$, and $\mathrm{Cl}$ ). A third aliquot was used to determine sediment concentration by filtering a known volume (approximately $100 \mathrm{ml}[3.4 \mathrm{oz}]$ ) through 0.45 -micron filter paper and weighing the dried filter paper.
The filtered water sample was analyzed by inductively coupled plasma optical emission spectroscopy for $\mathrm{P}, \mathrm{K}, \mathrm{Ca}, \mathrm{Mg}, \mathrm{Na}, \mathrm{Al}$, $\mathrm{Fe}, \mathrm{Mn}, \mathrm{Zn}$, and $\mathrm{S}$ concentrations, and by flow injection analysis for $\mathrm{NO}_{3}-\mathrm{N}, \mathrm{NH}_{4}-\mathrm{N}$, and $\mathrm{Cl}$ concentrations. An aliquot $(\sim 25 \mathrm{ml}$ [0.85 oz]) of the unfiltered water sample was digested with a Kjeldahl procedure (USEPA 1983) and analyzed by inductively coupled plasma optical emission spectroscopy for total $\mathrm{P}$ and by flow injection analysis for $\mathrm{NH}_{4}-\mathrm{N}$ for total $\mathrm{N}$.

The volume of flow at each site was calculated for each sample interval. This volume was multiplied by parameter concentrations from laboratory analysis to calculate mass loads. Loads were summed over appropriate intervals (e.g., yearly or monthly) to determine net input or output of a parameter. Flow-weighted concentrations were calculated by dividing the mass load for a time period by the total flow volume for the same period. Total salt concentration was calculated by multiplying electrical conductivity $\left(\mu \mathrm{S} \mathrm{cm}{ }^{-1}\right)$ by 0.64 .

Annual water balances for the Twin Falls tract were calculated as inflow plus precipitation minus return flow minus evapotranspiration. Precipitation was recorded at the Kimberly AgriMet weather station. Return flow includes both surface and subsurface flow. The balance accounts for all errors, evaporation from canals, and deep percolation. Salt and nutrient balances were total inflow minus total return flow. A positive balance indicated salts or nutrients were retained in the watershed, either in the soil or groundwater.

\section{Results and Discussion}

Annual water balances and salt and nutrients loads were calculated from May to April rather than the traditional October to September water year because our monitoring began in May 2005. Water balances for the first two years of monitoring are shown in table 2. Total input was similar for 2005 and 2006. However, above normal precipitation in 2005 contributed $24 \%$ of the total water input compared to $14 \%$ in 2006. Irrigation water in the TFCC Main Canal was the main hydrologic input to the watershed, supplying $73 \%$ of the water in 2005 and $83 \%$ in 2006. Less water was diverted in 2005 due to above normal precipitation in the spring and limited irrigation water supply (due to below normal winter snow 
in mountains). Irrigation diversions in 2005 and 2006 were $41 \%$ and $35 \%$ less than the 1969 water year (table 1), when water was diverted throughout the year and the Main Canal contributed $89 \%$ of the total input (Carter et al. 1971).

Crop water use and nongrowing season ET were estimated to be approximately half of the total water input to the watershed during 2005 and 2006 (table 2). Annual irrigation return flow was $580 \mathrm{~mm}$ (23 in) in 2005 and $650 \mathrm{~mm}$ (26 in) in 2006, or $37 \%$ and $43 \%$, respectively, of the total input to the irrigation tract. About $25 \%$ to $30 \%$ of the measured return flow occurred during the non-irrigation season as a result of subsurface drainage. Approximately $80 \%$ of the return flow was measured at primary monitoring sites that had data loggers and automatic samplers. The positive water balance indicates that water was stored within the watershed (i.e., groundwater recharge from canal seepage and deep percolation in furrow irrigated fields) during these two years. However, this balance also accounts for any measurement and estimation errors, which could be $\pm 10 \%$ for flow measurements and $\pm 20 \%$ for crop water use estimates. The balance also includes the quantity of water lost through evaporation from irrigation canals and groundwater return flow directly to the Snake River from unmonitored springs and seeps.

The Twin Falls irrigation tract still had a net loss of suspended sediment in 2005 and 2006 (table 3); however, current losses were much less than the $460 \mathrm{~kg} \mathrm{ha}^{-1}\left(410 \mathrm{lb} \mathrm{ac}^{-1}\right)$ measured during the 1971 irrigation season (table 1). Flow-weighted annual sediment concentrations in return flow were $99 \mathrm{mg}$ $\mathrm{L}^{-1}$ (99 ppm) in 2005 and $84 \mathrm{mg} \mathrm{L}^{-1}$ in 2006, compared to $300 \mathrm{mg} \mathrm{L}^{-1}$ calculated for the 1971 irrigation season (Carter et al. 1974). Converting to sprinkler irrigation, installing sediment ponds, changes in irrigation management, and using polyacrylamide are the primary conservation practices that we suspect contributed to reduced sediment loads in return flow streams (Bjorneberg et al. 2002). The difference in net sediment losses between 2005 and 2006 was due to differences in inflow sediment load, not return flow sediment loads (table 3 ). A preliminary analysis of 2007 data indicated that the inflow sediment load was low in 2005, possibly due to reduced irrigation diversion that year. Additional monitoring may show that annual net sediment loss is typically less

\section{Table 2}

Water balances for 2005 and 2006 for the Twin Falls irrigation tract.

\begin{tabular}{|c|c|c|c|}
\hline & & $\begin{array}{l}2005 \\
(\mathrm{~mm}) \\
\end{array}$ & $\begin{array}{l}2006 \\
(\mathrm{~mm}) \\
\end{array}$ \\
\hline \multirow[t]{4}{*}{ Input } & Main Canal & 1,140 & 1,260 \\
\hline & Rock Creek & 50 & 40 \\
\hline & $\underline{\text { Precipitation }}$ & 370 & 220 \\
\hline & Total & 1,560 & 1,520 \\
\hline \multirow[t]{3}{*}{ Output } & Return flow & 580 & 650 \\
\hline & Crop water use & 810 & 750 \\
\hline & Total & 1,390 & 1,400 \\
\hline Balance & & 170 & 120 \\
\hline
\end{tabular}

\section{Table 3}

Nutrient, soluble salt, and sediment balances for 2005 and 2006 for the Twin Falls irrigation tract.

\begin{tabular}{|c|c|c|c|c|c|}
\hline \multirow[b]{2}{*}{ Parameter } & & \multicolumn{2}{|l|}{2005} & \multicolumn{2}{|l|}{2006} \\
\hline & & $\mathrm{mg} \mathrm{L}^{-1}$ & kg ha $^{-1}$ & $\mathrm{mg} \mathrm{L}^{-1}$ & kg ha $^{-1}$ \\
\hline \multirow[t]{3}{*}{ Suspended solids } & Inflow & 29 & 350 & 41 & 530 \\
\hline & Outflow & 99 & 570 & 84 & 540 \\
\hline & Balance & & -220 & & -10 \\
\hline \multirow[t]{3}{*}{ Soluble salts } & Inflow & 280 & 3,400 & 250 & 3,300 \\
\hline & Outflow & 450 & 2,600 & 440 & 2,900 \\
\hline & Balance & & 800 & & 400 \\
\hline \multirow[t]{3}{*}{ Nitrate-N } & Inflow & 0.05 & 0.6 & 0.01 & 0.1 \\
\hline & Outflow & 2.01 & 11.6 & 2.30 & 14.8 \\
\hline & Balance & & -11.0 & & -14.7 \\
\hline \multirow[t]{3}{*}{ Dissolved $\mathrm{P}$} & Inflow & 0.07 & 0.89 & 0.04 & 0.47 \\
\hline & Outflow & 0.08 & 0.44 & 0.06 & 0.36 \\
\hline & Balance & & 0.45 & & 0.11 \\
\hline
\end{tabular}

than the $220 \mathrm{~kg} \mathrm{ha}^{-1}\left(200 \mathrm{lb} \mathrm{ac}{ }^{-1}\right)$ measured in 2005. We are also assuming that the 1971 irrigation season was a normal year and that sediment loads measured in 1971 are representative of average sediment loss for the conservation practices implemented at that time.

Compared to 1971 data, both inflow and outflow sediment loads have decreased (tables 1 and 3), which is noteworthy because Carter et al. (1974) only collected data from May to September. The net sediment loss from May to September 2005 was only 50 $\mathrm{kg} \mathrm{ha}^{-1}\left(44 \mathrm{lb} \mathrm{ac}^{-1}\right)$. There was a net gain of $130 \mathrm{~kg} \mathrm{ha}^{-1}\left(120 \mathrm{lb} \mathrm{ac}^{-1}\right)$ of sediment for the same time period in 2006.

If 1971 monitoring would have continued for the entire year, net sediment loss proba- bly would have been greater because outflow would continue to remove sediment from the watershed while little sediment would have been added after irrigation diversion ceased.

The Upper Snake River/Rock Creek CEAP monitoring indicated a net increase of total salts in the watershed (table 3). In 1969, Carter et al. (1971) calculated a net loss of $2,400 \mathrm{~kg} \mathrm{ha}^{-1}\left(2,100 \mathrm{lb} \mathrm{ac}^{-1}\right)$ total salts from the Twin Falls tract (table 1). The change from losing salts to retaining salts was possibly due to changes in irrigation conveyance and management practices that result in less deep percolation that ultimately becomes subsurface drainage, which has about twice the total salt concentration as irrigation water from the Snake River. The difference also 


\section{Figure 2}

Cumulative frequency distribution of total salt concentrations for two return flow streams and the Main Canal for 1969 to 1970 and 2005 to 2006 water years.
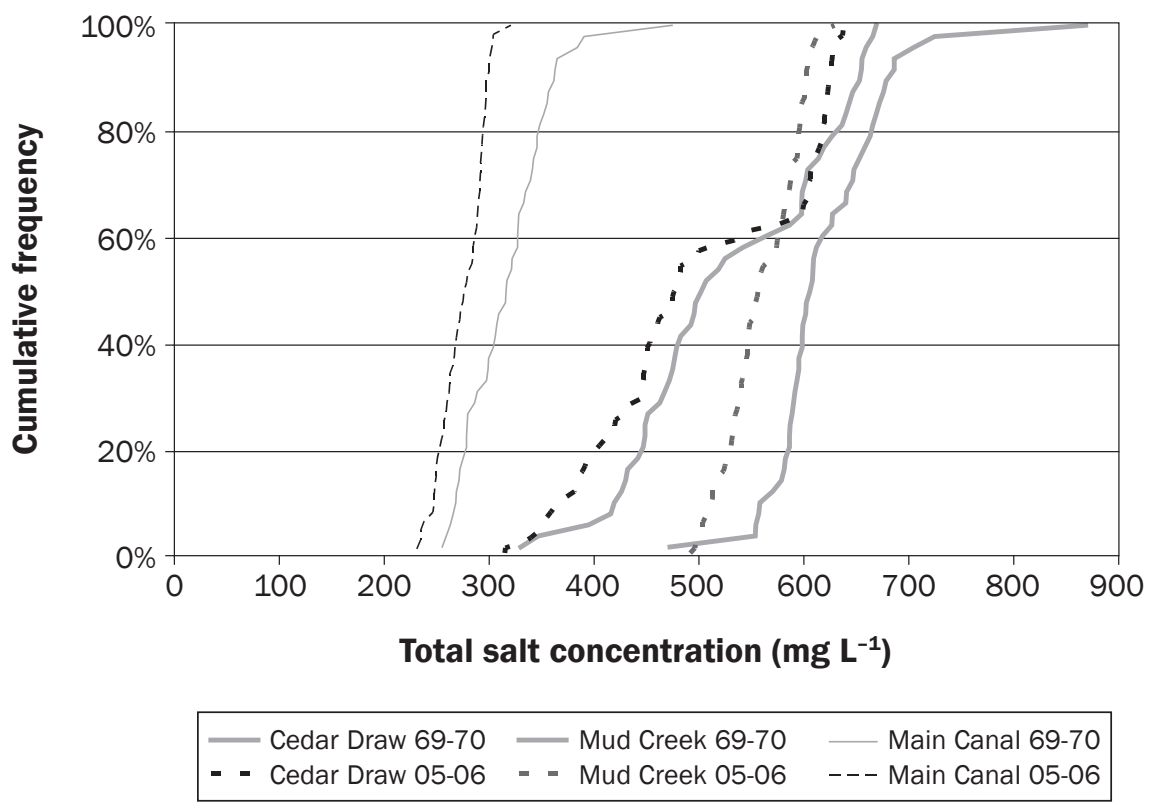

resulted from the assumption by Carter et al. (1971) that all water not accounted for by inflow, outflow, precipitation, and evapotranspiration was subsurface flow. Using that assumption with current data changed the net accumulation of total salts to a net loss

\section{Figure 3}

Cumulative frequency distribution of nitrate-nitrogen concentrations for two return flow streams and the Main Canal for 1969 to 1970 and 2005 to 2006 water years.

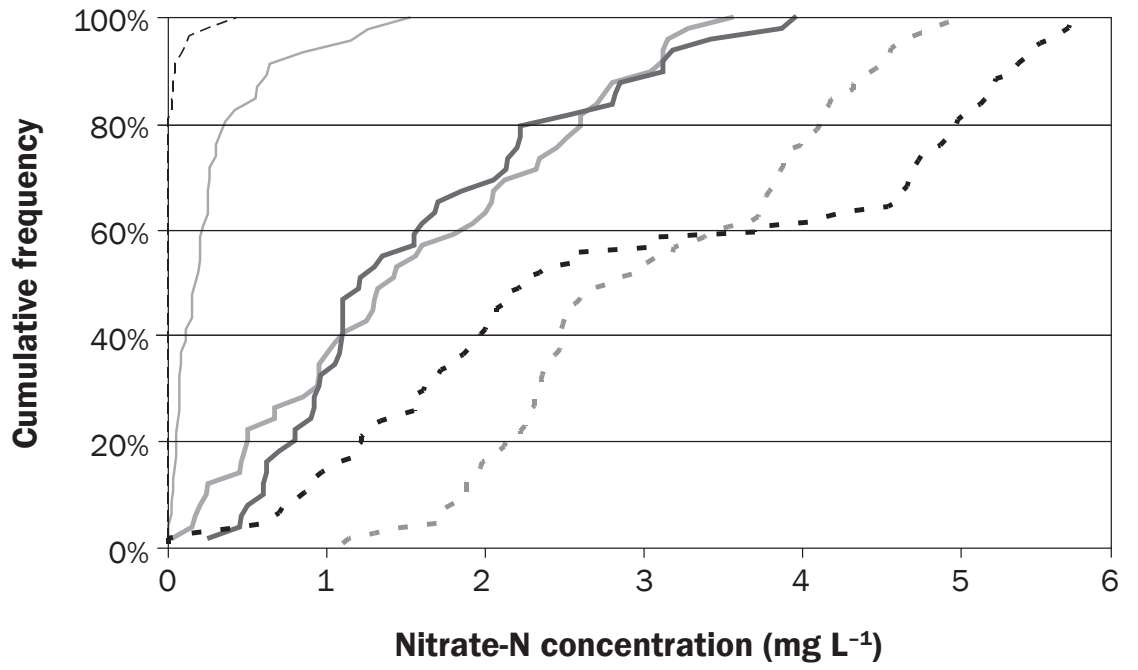

\begin{tabular}{|lll|}
\hline - Cedar Draw 69-70 & Mud Creek 69-70 & Main Canal 69-70 \\
- Cedar Draw 05-06 & $=$ - Mud Creek 05-06 & --- Main Canal 05-06
\end{tabular}

subsurface flow as was done by Carter et al. (1971) increased the nitrate-N loss to about $20 \mathrm{~kg} \mathrm{ha}^{-1}$ for both 2005 and 2006. Decreased nitrate losses could also indicate that less water percolated through the soil to subsurface drains, or that changes in other factors such as irrigation systems, fertilization practices, and crop types have reduced nitrate-N leaching. Nitrate-N concentrations were greater in watershed outflow than inflow (table 3) because nitrate-N leached from the soil as water flowed to subsurface drains. Dissolved P concentrations were low but also appeared to be greater in watershed outflow (table 3). The Twin Falls irrigation tract, however, continued to remove dissolved $\mathrm{P}$ from the Snake River, although the net gain in the watershed was less than $1 \mathrm{~kg} \mathrm{ha}^{-1}\left(0.9 \mathrm{lb} \mathrm{ac}^{-1}\right)$ in 2005 and 2006 (table 3).

Water quality monitoring for the Upper Snake River/Rock Creek CEAP included more return flow sites than the previous studies. Direct comparisons of water quality data were made with data reported by Carter et al. (1973) for the 1969 and 1970 water years. This report contained monthly flow and biweekly water quality data, which unfortunately did not include sediment concentrations, for the TFCC Main Canal and four main return flow streams in the Twin Falls irrigation tract. These four return flow streams contributed $75 \%$ of the total return flow to the Snake River in 2005 and 2006 (data not shown). Cumulative frequency distributions of total salt concentrations showed that total salts were similar or decreased slightly in return flow streams and the Main Canal between 1969 to 1970 and 2005 to 2006. Figure 2 shows total salt concentration distributions for two return flow streams and the Main Canal as an example. All three sites had greater maximum concentrations in 1969 to 1970 than 2005 to 2006. The inflection point at $60 \%$ for Cedar Draw (figure 2) occurred because total salt concentration increased after the irrigation season when most, if not all, of the flow was subsurface drainage. Note that the irrigation season was approximately $60 \%$ of the year (April through October) so $60 \%$ of the samples should have had lower concentrations. The lack of an inflection point for Mud Creek indicates that this return flow stream had less seasonal influence from surface drainage. A cursory mass balance was calculated assuming the surface drainage concentration equaled the 
Table 4

Total annual flow and total salt, nitrate-nitrogen, and dissolved phosphorus loads for the Main Canal and four return flow streams.

\begin{tabular}{|c|c|c|c|c|c|c|}
\hline & Main Canal & Rock Creek & Cedar Draw & Mud Creek & Deep Creek & Total outflow \\
\hline \multicolumn{7}{|c|}{ Flow $\left(10,000 \mathrm{~m}^{3}\right)$} \\
\hline 1969 & 159,000 & 17,900 & 3,310 & 9,170 & 8,990 & 39,400 \\
\hline 1970 & 146,000 & 17,300 & 4,840 & 8,530 & 9,810 & 40,400 \\
\hline 2005 & 93,600 & 17,800 & 6,460 & 6,730 & 4,780 & 35,700 \\
\hline 2006 & 103300 & 19,600 & 7,650 & 6,400 & 6,160 & 39,800 \\
\hline \multicolumn{7}{|c|}{ Total salts (Mg) } \\
\hline 1969 & 470,000 & 93,700 & 15,900 & 57,000 & 41,300 & 207,900 \\
\hline 1970 & 421,000 & 86,600 & 24,400 & 51,400 & 42,800 & 205,100 \\
\hline 2005 & 274,000 & 70,900 & 30,000 & 38,100 & 22,900 & 162,000 \\
\hline 2006 & 267,000 & 83,600 & 34,200 & 35,300 & 28,600 & 181,800 \\
\hline \multicolumn{7}{|c|}{ Nitrate-N (Mg) } \\
\hline 1969 & 152 & 146 & 35 & 153 & 107 & 440 \\
\hline 1970 & 149 & 148 & 64 & 125 & 83 & 419 \\
\hline 2005 & 45 & 299 & 136 & 185 & 106 & 726 \\
\hline 2006 & 6 & 418 & 169 & 206 & 163 & 956 \\
\hline \multicolumn{7}{|c|}{ Dissolved P (Mg) } \\
\hline 1969 & 84 & 21 & 3 & 5 & 5 & 34 \\
\hline 1970 & 89 & 19 & 4 & 6 & 4 & 32 \\
\hline 2005 & 71 & 13 & 5 & 5 & 3 & 28 \\
\hline 2006 & 38 & 10 & 4 & 4 & 3 & 22 \\
\hline
\end{tabular}

Note: Data for 1969 and 1970 taken from Carter et al. (1973).

average Main Canal concentration and the subsurface drainage concentration equaled the winter concentration for 2005 to 2006 , when no irrigation water was diverted, and $665 \mathrm{mg} \mathrm{L}^{-1}$ for the earlier study (Carter et al. 1973), when irrigation water was diverted all year. This mass balance indicated that about half of the flow in Cedar Draw during the irrigation season was subsurface drainage compared to $80 \%$ in Mud Creek.

Nitrate-N concentrations increased in the two return flow streams between 1969 to 1970 and 2005 to 2006 but decreased in the Main Canal (figure 3). About 60\% of the samples were less than $2 \mathrm{mg} \mathrm{L}^{-1}$ in 1969 to 1970 , while only $15 \%$ of the samples from Mud Creek and $40 \%$ of the samples from Cedar Draw were less than $2 \mathrm{mg} \mathrm{L}^{-1}$. Dissolved $\mathrm{P}$ concentrations in the return flow streams have changed little between 1969 and 2006, with the exception of three samples greater than $0.2 \mathrm{mg} \mathrm{L}^{-1}$ in 2005 to 2006 (figure 4). Main Canal dissolved P concentrations decreased. Decreased nitrate-N and dissolved $\mathrm{P}$ concentrations in the Main Canal could be the result of reduced wastewater loading to the Snake River upstream from Milner Dam.

\section{Figure 4}

Cumulative frequency distribution of dissolved phosphorus concentrations for two return flow streams and the Main Canal for 1969 to 1970 and 2005 to 2006 water years.

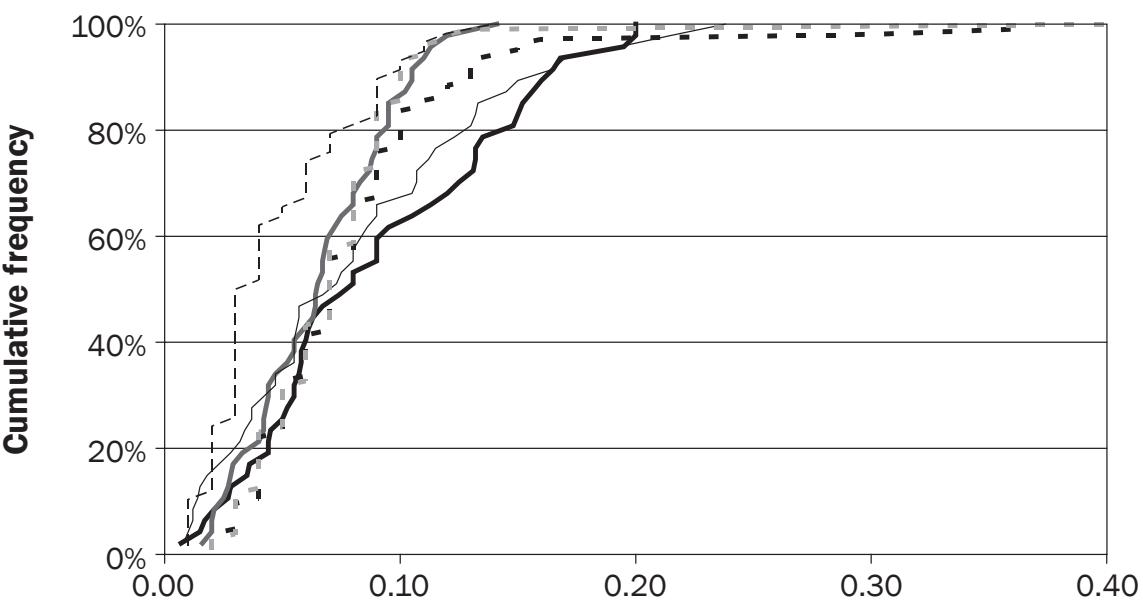

Dissolved phosphorus concentration ( $\left.\mathrm{mg} \mathrm{L}^{-1}\right)$

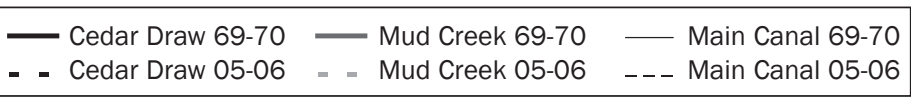


Table 5

Total subwatershed outflow and loads for 2005 and 2006.

\begin{tabular}{|c|c|c|c|c|c|c|c|c|}
\hline \multirow[b]{3}{*}{ Site } & \multirow[b]{3}{*}{ Area (ha) } & \multirow{3}{*}{$\begin{array}{l}\text { Sprinkler } \\
\text { irrigation }\end{array}$} & \multirow{2}{*}{\multicolumn{2}{|c|}{ Flow (mm) }} & \multicolumn{4}{|c|}{ Total suspended sediment } \\
\hline & & & & & \multicolumn{2}{|c|}{ Concentration (mg L ${ }^{-1}$ ) } & \multicolumn{2}{|c|}{ Load (kg ha-1) } \\
\hline & & & July & Season & July & Season & July & Season \\
\hline PC1 & 354 & $5 \%$ & 26 & 90 & 1,000 & 600 & 270 & 530 \\
\hline EC & 604 & $15 \%$ & 53 & 320 & 750 & 430 & 400 & 1,400 \\
\hline TF1 & 174 & $19 \%$ & 70 & 220 & 1,900 & 1,000 & 1,300 & 2,300 \\
\hline TF3 & 152 & $51 \%$ & 38 & 210 & 490 & 800 & 190 & 1,700 \\
\hline \multicolumn{9}{|c|}{2006} \\
\hline PC1 & 354 & $5 \%$ & 22 & 120 & 1,600 & 650 & 359 & 810 \\
\hline $\mathrm{EC}$ & 604 & $15 \%$ & 97 & 590 & 640 & 360 & 620 & 2,100 \\
\hline
\end{tabular}

Increased nitrate- $\mathrm{N}$ concentrations contradicts the reduced net loss of nitrate-N from the entire Twin Falls irrigation tract shown in tables 1 and 3. The methods used by Carter et al. (1971) to calculate total subsurface flow may have over-estimated, relative to Upper Snake River/Rock Creek CEAP monitoring, the total nitrate- $\mathrm{N}$ load leaving the irrigation tract. Furthermore, there may be an overall reduction in subsurface drainage from the Twin Falls irrigation tract, which would reduce nitrate-N loss. Comparing only the four main return flow streams between 1969 to 1970 and 2005 to 2006 shows that total return flow was unchanged, total salt load decreased, nitrate$\mathrm{N}$ load increased, and dissolved $\mathrm{P}$ load decreased (table 4).

Subwatersheds. Initial analysis of subwatershed data showed no significant correlations between total annual outflow and loads and the amount of sprinkler irrigation for 2005 and 2006. As noted previously, the TFCC allocates water on a flow rate basis so farmers do not have an incentive to stop receiving irrigation water when they are not irrigating. Therefore, there is a tendency for irrigation water to flow through the watershed in the spring and fall when irrigation demand is low. Comparing concentrations or loads on only an annual basis may overlook some differences occurring during the summer when irrigation demand is greatest and row crops, which have greater erosion rates, are being irrigated. The relative amount of sprinkler irrigation in a subwatershed did not correlate with the total loss of suspended sediment for July 2005 and $2006(r=0.12)$.
The lack of correlation was primarily due to extremely high sediment concentrations in TF1 and TF3 subwatersheds (table 5). These high concentrations could be due to furrow irrigation management and distribution of furrow irrigated row crops within these subwatersheds. Visual observations in TF1 indicated excessive erosion on furrow irrigated fields. In TF3, a 3.5-ha (9-ac) furrow irrigated dry bean field was adjacent to the outlet in 2006 when July flow-weighted sediment concentration was $3,700 \mathrm{mg} \mathrm{L}^{-1}$ compared to $490 \mathrm{mg} \mathrm{L}^{-1}$ in 2005 when the same field was alfalfa.

Within each subwatershed, there were many factors potentially affecting sediment and nutrient losses besides sprinkler irrigation. Possibly the most important difference was furrow irrigation management, which is difficult to quantify without measuring runoff from each field in the subwatersheds. More detailed analysis of furrow irrigated field locations within each subwatershed is planned to try to explain differences in sediment and nutrient losses among subwatersheds.

Average annual sediment loss from the subwatersheds over the two-year monitoring period was $2,230 \mathrm{~kg} \mathrm{ha}^{-1}\left(1,990 \mathrm{lb} \mathrm{ac}^{-1}\right)$, which is much greater than the sediment loss rates for the entire watershed $\left(560 \mathrm{~kg} \mathrm{ha}^{-1} \mathrm{y}^{-1}\right.$ $\left.\left[500 \mathrm{lb} \mathrm{ac}^{-1} \mathrm{yr}^{-1}\right]\right)$. These high sediment losses indicate a continued need for field-level conservation practices. The large decrease in sediment loss between the outlets of the subwatersheds and the return points to the Snake River could be a result of sediment basins constructed throughout the Twin Falls irrigation tract. An on-going study will quantify the effectiveness of these ponds. Although sediment basins decrease sediment load to the river and improve water quality, they do not reduce erosion rates. Conservation practices that reduce field-scale erosion would benefit crop production as well as improve water quality.

\section{Summary and Conclusions}

For the years 2005 and 2006, monitoring for the Upper Snake River/Rock Creek CEAP indicated that water quality has improved since similar data were collected in 1968 to 1971. Net loss of suspended sediment for the Twin Falls irrigation tract during the 1971 irrigation season was $460 \mathrm{~kg} \mathrm{ha}^{-1}$ $\left(400 \mathrm{lb} \mathrm{ac}^{-1}\right)$. This decreased to $220 \mathrm{~kg} \mathrm{ha}^{-1}$ $\left(190 \mathrm{lb} \mathrm{ac}^{-1}\right)$ in 2005 and $10 \mathrm{~kg} \mathrm{ha}^{-1}\left(9 \mathrm{lb} \mathrm{ac}^{-1}\right)$ in 2006. Flow-weighted sediment concentration of all water returning was $99 \mathrm{mg} \mathrm{L}^{-1}$ in 2005 and $84 \mathrm{mg} \mathrm{L}^{-1}$ in 2006, compared to $300 \mathrm{mg} \mathrm{L}^{-1}$ during the 1971 irrigation season. Two potential concerns were identified with this initial analysis: accumulation of total salts and increased nitrate- $\mathrm{N}$ concentrations in at least four return flow streams. Furthermore, sediment concentrations in outflow from five subwatersheds did not correlate with the relative amount of sprinkler irrigation, probably due to differences in furrow irrigation management and distribution of crops within the subwatersheds. Exact cause-effect relationships have not been identified in this initial analysis. A major obstacle to improving the decision making process for conservation practice implementation in the Upper Snake River/Rock Creek CEAP and similar irrigated watersheds is the lack of a water quality 
model for simulating irrigation distribution, runoff and return flows. The inability to predict sediment and nutrients transported from irrigated fields limits land managers' ability to choose the most appropriate areas to apply conservation practices and evaluate effects of these practices. Incorporating irrigation erosion in a watershed water quality model is a top priority for future Upper Snake River/ Rock Creek CEAP research.

\section{Acknowledgements}

Partial support for this Conservation Effects Assessment Project was provided by the USDA Natural Resources Conservation Service.

\section{References}

Allen, R.G., and C.W. Robison. 2007. Evapotranspiration and Consumptive Irrigation Water Requirements for Idaho. Kimberly, ID: University of Idaho. http://www. kimberly.uidaho.edu/ETIdaho/.

Berg, R.D., and D.L. Carter. 1980. Furrow erosion and sediment losses on irrigated cropland. Journal of Soil and Water Conservation 35(6):267-270.

Bjorneberg, D.L., C.J. Prestwich, and R.G. Evans. 2007. Evaluating the surface irrigation soil loss (SISL) model. Applied Engineering in Agriculture 23(4):485-491.

Bjorneberg, D.L., D.T. Westermann, and J.K. Aase. 2002. Nutrient losses in surface irrigation runoff. Journal of Soil and Water Conservation 57(6):524-529.

Brown, M.J., D.L. Carter, and J.A. Bondurant. 1974. Sediment in irrigation and drainage waters and sediment inputs and outputs for two large tracts in southern Idaho. Journal of Environmental Quality 3(4):347-351.

Carter, D.L., J.A. Bondurant, and C.W. Robbins. 1971. Water-soluble $\mathrm{NO}_{3}$-nitrogen, $\mathrm{PO}_{4}$-phosphorus, and total salt balances on a large irrigation tract. Soil Science Society of American Proceedings 35(2):331-335.

Carter, D.L., M.J. Brown, C.W. Robbins, and J.A. Bondurant. 1974. Phosphorus associated with sediments in irrigation and drainage waters for two large tracts in southern Idaho. Journal of Environmental Quality 3(3):287-291.

Carter, D.L., C.W. Robbins, and J.A. Bondurant. 1973. Total salt, specific ion, and fertilizer element concentrations and balances in the irrigation and drainage waters of the Twin Falls tract in southern Idaho. ARS-W-4. Kimberly, ID: USDA Agricultural Research Service. http://eprints.nwisrl.ars.usda.gov/1101/NASS.

Moon, J.H., and R.M. Tremayne. 2005. A History of the Twin Falls Canal Company. Twin Falls, ID: Blip Printers.

US Bureau of Reclamation. 2007. AgriMet-The Pacific Northwest Cooperative Agricultural Weather Network. http://www.usbr.gov/pn/agrimet/.

US Census Bureau. 2007. Population Estimates. Washington, DC: Population Division, US Census Bureau. http:// www.census.gov/popest/estimates.php.

USDA NASS (National Agricultural Statistics Service). 2007. Agricultural Statistics Service Data Base.Washington,DC: USDA National Agricultural Statistics Service. http:// www.nass.usda.gov/Data_and_Statistics/Quick_Stats/.

USEPA (US Environmental Protection Agency). 1983. Methods for Chemical Analysis of Water and Wastes, EPA-600/4-79-020. Revised March 1983, Method 351.2 . 